\title{
Academic Motivation Levels of Secondary School Students and Their Attitudes towards a Social Studies Course
}

\author{
Melike FAiz' \\ Kastamonu University, Kastamonu, TURKEY
}

\author{
Emine KARASU AVCl${ }^{2}$ \\ Kastamonu University, Kastamonu, TURKEY
}

\begin{abstract}
${ }^{1}$ Assist. Prof. Kastamonu University, Department of Social Studies Education, Kastamonu, Turkey. mfaiz [at] kastamonu.edu.tr ORCID: 0000-0001-8070-6086

2 Corresponding author: Assist. Prof. Kastamonu University, Department of Social Studies Education, Kastamonu, Turkey. eavci [at] kastamonu.edu.tr I ORCID: 0000-0002-3135-2557
\end{abstract}

\section{Abstract}

The present study aims to reveal the motivation levels of secondary school students and their attitudes towards a Social Studies course. This study employed a mixed method approach. The quantitative data were collected through the use of an "Academic Motivation Scale" and an "Attitude Scale for a Social Studies Course". The qualitative data were obtained through a structured interview. Four hundred and forty-three secondary school students participated in the quantitative part of the study, while fourty-five secondary school students participated in the qualitative part of the study. The results of the quantitative section are given in two separate parts: a motivation scale, and an attitude scale. A significant difference was observed in the introjected regulation levels of male secondary school students. The scores for identified regulation and motivation were in favor of female students. There was no difference in the motivation scores according to the socio-economic levels of the students. However, the motivation levels of the students decreased as the grade level increased. The attitudes of participants towards the Social Studies course did not differ according to both gender and grade level of the participants. According to the school variable, a difference was observed between schools with a low socio-economic status and those with high socio-economic status. The qualitative data revealed a majority of students had positive attitudes towards the Social Studies course. Furthermore, the factors that enhance student motivation towards the Social Studies course were found to be related to the study of History, having an interest in the course, and the way the course is taught.

\section{Keywords}

Academic Motivation, Attitude, Social Studies, Secondary School, Student 
Motivation is derived from the Latin words "movere" and "motum" (Selen, 2016) and also from the English and French word "motive"; the Turkish equivalent of motivation is known as "incentive" or "starting to move". Motivation is a general concept that includes the desires, wishes, needs, interests and impulses of individuals (Akman, 2011). In the literature, motivation is defined as (i) an inner drive and individual focus on a specific goal with a display of purposive behavior (Çiçek, 2005); (ii) making an effort to act consistently in accordance with a specific purpose (Ergül, 2005; Karacelil, 2013); and also as (iii) the strength of individuals to overcome challenges (Tohidi \& Jabbari, 2012). Therefore, motivation can be described as the strength, inner motive and drive to take action, and the energy that an individual has to satisfy their needs and achieve their goals.

Motivation is influenced by natural and logical motives. While hunger, sleep and social needs are natural motives, the logical motives include processes such as reasoning, knowledge, memory, judgment, decision-making and problem solving. As a result, the source of motivation can be analyzed as being internal or external. Intrinsic, or internal motivation refers to the motives that an individual develops which are independent of external influences (Seker, 2015). Such motives can be regarded as the inner feelings of an individual (Stirling, 2013). Extrinsic, or external motivation arises from outside the individual, with either the expectancy of a reward or the aim of avoiding punishment (Seker, 2015). Such motives encourage the individual to take actions that are perceived as inherently unpleasant but may help them in terms of avoiding potential consequences (Stirling, 2013).

Motivation occurs consciously or unconsciously by everyone in all fields of life. Within the family environment, parents motivate their children in order to teach new behaviors. Countries also motivate their citizens to live in accordance with the rules of law and to contribute to social life. In this context, motivation is the easiest and most important method to direct or influence human behavior (Karacelil, 2013). Motivation ensures that individuals are willing, efficient and active without pressure and constraint (Vatansever-Bayraktar, 2015). The needs, desires and expectations of people differ, however, an ability to increase the motivation of individuals occurs by meeting their needs, wishes and expectations (Karakaya \& Ay, 2007).

As in every aspect of life, motivation is the most important component of success and effective teaching in the field of education. Individuals with high levels of motivation are also often successful and self-confident in their social life. Such individuals experience success in their education. The level of motivation held by an individual is an important factor to consider in the design of effective education and training activities (Ergin \& Karataş, 2018). Educators aim to maximize learning by motivating students. The motivation levels of students can be increased by enabling them to (i) develop their relationships with classmates; and (ii) participate in school and classroom activities. Motivation levels of students can also be increased through teacher-reinforcement of positive behaviors, and by meeting student learning needs. Aktaş (2016) together with Vero \& Puko (2017) point out that motivation is important to improve student learning because motivation and learning processes are interrelated. Without striving for a goal through motivation, it is not possible for students to achieve 
anything, not only in education but also in real life. In this sense, it can be said that motivation is an inner power which encourages students to face their challenges in the learning process (Gopala, Bakar, Zulkifli, Alwi \& Mat, 2017).

During their school life, students are confronted with a lot of educational attainment activities, such as exams and assignments; and differences occur amongst students in the way they fulfil all these responsibilities. An understanding about the different motivation levels of students helps to explain such a phenomenon (Aktaş, 2016; Çolak \& Cirık, 2015). Motivation is a source of power that determines the direction, severity, and stability of student behavior, in addition to influencing the speed at which the desired goal is achieved. The origin of learning disabilities and disciplinary events in school and classroom settings are related to motivation. An increase in levels of motivation contributes to (i) students' enjoying the school experience; (ii) fostering their positive thinking and attitudes towards the school and its courses; and (iii) develops student awareness about their responsibilities (Arıkıl \& Yorgancl, 2012). For instance, if a person is full of energy and being proactive in taking action, they are said to be motivated. However, the person is said to be not motivated if they do not feel up to taking action on a particular task. Thus, motivation is the basic instinct for performing or not performing an action (Gömleksiz \& Serhatlıoğlu, 2013). For this reason, motivation is directly influential in developing attitudes towards wanting to learn and also in the realization of what constitutes effective learning (Baykara-Özaydınlık \& Aykaç, 2014). To meet the expectations of students will increase their motivation and also enhance their performance (VatanseverBayraktar, 2015). To arouse the curiosity of students and ensure their willingness to engage with and complete the course will positively affect their motivation (Altun \& Yazıcı, 2010). In this regard, academic motivation can be defined as the willingness to attain specific academic objectives by students (Wilkesman, Fischer \& Virgilito, 2012). Students whose academic motivation levels are high are more open to learning and will have a stronger interest in the course. Academic motivation is also important for students to solve the problems they encounter as part of the learning process.

It is believed that an increase in an individuals' level of learning will occur when an appropriate learning environment is provided. However, this situation does not apply in the same way for each student. Students may not always be open and willing to learn. This shows that affective processes are also important in learning. To understand the importance of learning, and to want to learn and to study are all related to the attitude of the student (Akpınar, 2006). At this point, it will be appropriate to explain the term 'attitude' as a concept that effects student success.

Attitude was identified as a key concept of socio-psychology in the 1940s. Attitude has been defined as an emotional tendency of the individual for and against an object, an event, a set of ideas, or another individual, or any stimulus; attitude is also defined as the manner displayed and the tendency to consistently react in a learned way (Kazazoğlu, 2011; Lukow, 2002; Oppenheim, 1966; Papanastasiou, 2002; Tütüncü \& Küçükusta, 2007).

Attitudes are acquired through experience, not by birth. Family, friends and media shape the attitudes of an individual. Attitudes are an important factor in behavior formation (Karakuş-Tayşi \& Özbay, 2016). Although attitude is a socially- 
based concept in terms of its formation and relevant subjects, it is also an outcome of the psychology and behavior of the individual (Tütüncü \& Küçükusta, 2007). Arslan (2006) expresses that attitudes are formed as a result of a series of interactions; however, attitudes may change suddenly as a result of a single experience or they may change gradually as a result of a series of experiences. This variability in the development of attitude facilitates the adaptation of individuals to their environment (Sardarov, 2012). Attitudes are the basis of the behaviors we display in our daily lives. Our likes, preferences, and feelings of love and hatred can be explained by our attitudes (Çöllü \& Öztürk, 2006). Individual attitudes are revealed through their knowledge, expectations, and beliefs and judgments about events and situations (Akpınar, 2006). The measurement of attitudes accurately provides an accurate estimation of behaviors. For this reason, to identify attitudes is also important for educators.

Educators consider attitude as an element that has an impact in the process of learning and teaching (Öztürk \& Kalyoncu, 2014). The feelings of students displayed towards their course, teachers, school, friends, exams, and course materials indicate their attitude (Kazazoğlu, 2011). Attitudes are important in terms of creating environments conducive to learning. The positive or negative attitudes of students towards a course can impact on their levels of academic achievement (Gömleksiz \& Kan, 2013). Bloom (1995) indicates that students who treat a subject with excitement and interest can learn better than the students who are not interested and excited. Positive attitudes of students towards learning will increase their interest in the course and in the learning process, however, negative attitudes will lead to indifference and failure. Therefore, it is necessary to develop positive attitudes towards learning in order to gain success (Akpınar, 2006).

According to Das, Halder, Mishra \& Delnath (2014), attitude is an important element which affects academic success. The ability of students to cope with the difficulties of learning a subject is realized by their attitudes towards the course. Adigüzel (2012) also states that if the attitude of a student towards a course is negative, it can be the reason for their failure. Özçelik (1992) indicates that knowing what individuals are affectively ready to learn about and are interested in learning will be effective for student learning. The main factors of student success in a course are related to the interest and attitudes of student towards the course. For the student to like the course, to be interested in the course, and to develop a positive attitude towards the course will depend on various factors such as liking the teacher, and having an interest in the course subject. Controlling these variables will help the student develop a positive attitude towards the course and will therefore have an effect on academic motivation.

In the literature, the relationship between motivation and attitude are revealed through studies completed mostly in the field of science education. Such studies examine the effect of motivation and attitude towards success in Science courses (Ceylan, Sağırekmekçi, Tatar \& Bilgin, 2016); the improvement of motivation and attitude towards a course through nature education projects (Türk, Kalkan, Semercioğlu \& Bolat, 2017); the effect of ARCS model of motivational design on the motivation, attitude and academic achievement of 
students (Balantekin \& Bilgin, 2017); and the relationship between motivation and attitudes of students towards Turkish course (Fidan \& Altay, 2017).

There is no known study about the relationship between motivation and attitude in Social Studies courses. The positive academic motivation and attitudes of students in a Social Studies course will have a positive effect on their academic achievement in the course. Özkal, Güngör \& Çetinöz (2004) stated that positive attitudes towards Social Studies courses which aim to educate individuals about taking action in a democratic world, is highly important. In addition, Fidan \& Altay (2017) expressed that it is important to examine the relationship between motivation and attitude for secondary school students. A review of the literature from the field of education reveals there is a need for examining the relationship between motivation and attitude towards a Social Studies course. If a student's attitude and motivation towards a lesson is high, they will be more successful in their lessons and will learn more easily. For this reason, it is important to determine the levels motivation and attitudes of students towards a Social Studies course, and to also determine the relationship between motivation and attitudes.

The aim of the study is to reveal the relationship between the motivation levels and attitudes of secondary school students (students aged 11-13) towards a Social Studies course. The research questions are:

1. What are the motivation levels of the secondary school students?

2. Is there a significant difference between the motivation of secondary school students and their gender, school, and grade level?

3. What are the attitudes of secondary school students towards a Social Studies course?

4. Is there a significant difference between the attitudes of secondary school students and their gender, school, and grade level?

5. Is there a relationship between the academic motivation levels of secondary school students and their attitudes towards a Social Studies course?

6. What factors motivate secondary school students towards a Social Studies course?

7. What are the positive and negative attitudes of secondary school students towards a Social Studies course?

\section{Methodology}

\section{Research Design}

In this research, a mixed methods triangulation approach is used. The purpose of triangulation is to test the existence of approximate or consistent results by applying both qualitative and quantitative research methods to the same hypothesis independently. In other words, the proximity or consistency of the results obtained from different methods and designs is investigated. Triangulation increases the opportunity of controlling, or at least evaluating, several causes that affect the results of the research (Giannakaki, 2005; Greene \& Caracellive Graham, 1989). In this study, a triangulation method was preferred to determine the existence of approximate or consistent results, and to determine the 
Faiz, M.; Karasu Avcl, E. (2020). Academic Motivation Levels of Secondary School Students...

consistency of different methods. The qualitative part of data collection was included to support the quantitative part of data collection.]

\section{Study Group}

The current study was conducted at several secondary schools in a city in northern Turkey. A total of 443 secondary school students $\left(97\right.$ from $5^{\text {th }}$ grade, 199 from 6th grade, and 147 from 7th grade) participated in the quantitative part of the study. In the qualitative part of the study, a total of 45 students participated: 15 students from each of the $5,6^{\text {th }}$, and 7 th grade levels. Stratified sampling was used when selecting the study groups. The reason for choosing stratified sampling is to understand the sub-groups. The sub-groups, from the overall study group, were determined according to the variables: socio-economic level and student's school success, because such variables are thought to have an effect on the attitude and motivation of the student. Stratified sampling is a type of sampling method where the entire population is divided into homogeneous groups called strata, and each entity in the population is covered. Division into the sub-groups is carried out so that within-strata-variance is as homogeneous as possible, and the inter-strata variance also remains as heterogeneous as possible. After division, the sample is drawn from each stratum separately and independently. Stratified sampling is used when sub-strata or sub-entity groups exist in a defined population (Çıngı, 1994; Dawson \& Trapp, 2001; Gay, 1987; Özdamar, 2001). While forming the strata, 10 teachers and 4 school administrators working in a city in Turkek were interviewed and the answers they gave were taken into consideration. Demographic information about the secondary school students who participated in the quantitative part of the study are shown in Table 1. The school with low socio-economic status is called LL (School 1), the one with middle socio-economic status is called IL (School 2) and the other school with high socioeconomic status is called HL (School 3). These schools are called in the findings part of this study as L.L. for the one with low status; I.L for the one with middle status, and H.L. for the one with high status.

Table 1

The Demographic Information of Participants from the Quantitative Part of the Research

\begin{tabular}{lll}
\hline Gender & $f$ & $\%$ \\
\hline Female & 220 & 49.7 \\
Male & 223 & 50.3 \\
\hline Grade Level & $\mathrm{f}$ & $\%$ \\
\hline 5 & 97 & 21.9 \\
6 & 199 & 44.9 \\
7 & 147 & 33.2 \\
\hline School & $\mathrm{f}$ & $\%$ \\
\hline School 1 & 179 & 40.4 \\
School 2 & 142 & 32.1 \\
School 3 & 122 & 27.5 \\
Total & 443 & 100 \\
\hline
\end{tabular}

Table 1 shows that 220 female and 223 male students participated in the quantitative part of the study. The distribution of grades levels are 97 students in Grade 5, 199 students in Grade 6, and 147 students in Grade 7. The distribution of participants across the schools are 179 students from LL School 1, 147 students from IL School 2, 122 students from HL School 3. 
For the students participating in the qualitative part of the research, the sample type was determined as a convenience sample. Convenience sampling is to select the sample from easily accessible and applicable units due to the limitations in terms of time, money and labor (Dawson \& Trapp, 2001).

Table 2

Demographic Information of Participants' from the Qualitative Part of the Research

\begin{tabular}{ccccccc}
\hline \multirow{2}{*}{ Grade Level } & \multicolumn{2}{c}{ Female } & \multicolumn{2}{c}{ Male } & \multicolumn{2}{c}{ Total } \\
\cline { 2 - 7 } & $\mathbf{f}$ & \% & $\mathbf{f}$ & $\mathbf{9}$ & $\mathbf{f}$ & \% \\
\hline 5 & 6 & 30 & 9 & 36 & 15 & 33.3 \\
6 & 5 & 25 & 10 & 40 & 15 & 33.3 \\
7 & 9 & 45 & 6 & 24 & 15 & 33.3 \\
Total & 20 & 100 & 25 & 100 & 45 & 100 \\
\hline
\end{tabular}

20 female and 25 male participants participated in the qualitative part of the study. There are 6 female students and 9 male students in Grade 5; there are 5 female students and 10 male students in Grade 6; and there are 9 female students and 6 male students in Grade 7.

\section{Data Collection and Data Processing}

In the current studies were used to collect data in the quantitative part:

- the "Academic Motivation Scale" developed by Vallerand et al. (1989) and adapted into Turkish language by Yurt \& Bozer (2015); and

- the "Attitude Scale for Social Studies Course" developed by Demir \& Akengin (2010).

The scales reveal the level of abstract structures that cannot be directly observed in individuals (DeVellis, 2012). The attitude scales and the motivation scales/tests are both an affective test and a scale. These tests can be used to gather information about individuals. Objective measurement tools are used to gather information about the psychological features of individuals because such features are difficult to directly observe. These tests can be performed easily, are scored in an objective way, and enable valid and reliable observations to occur (Cronbach, 1990; Kepçeoğlu, 1995; Özgüven, 1994; Özgüven, 1998). For this reason, such tests were used in our study. In addition, there is no study dealing with students' attitude and motivation in terms of different variables. (Balantekin \& Bilgin, 2017; Bektaş \& Karagöz, 2017; Ceylan, Sağırekmekçi, Tatar \& Bilgin, 2016; Coşkun, 2009; Dolunay, 2010; Fidan \& Altay, 2017; Kaya \& Nazıroğlu, 2008; Meriç, 2014; Türk, Kalkan, Semercioğlu \& Bolat, 2017; Yetim, Demir \& Erduran-Illker, 2014).

The scale was adapted by Yurt \& Bozer (2015) from Vallerend et al (1992); the scale is composed of 28 items and related information is given below in Table 3. In the data collection tool, the rating was evaluated from 1 (no match) to 7 (full match). The evaluation is taken as a baseline for this research. Since the items from the amotivation sub-scale (scale items 5, 12, 19 and 26) were negative statements, they were reversely coded. 
Faiz, M.: Karasu Avcl, E. (2020). Academic Motivation Levels of Secondary School Students...

Table 3

The Reliability of the "Academic Motivation Scale"

\begin{tabular}{l|l|l|l}
\hline Subscales & $\begin{array}{l}\text { Vallerend } \\
\text { et al. (1992) }\end{array}$ & $\begin{array}{l}\text { Yurt and } \\
\text { Bozer } \\
\mathbf{( 2 0 1 5 )}\end{array}$ & In this study \\
\hline Intrinsic motivation to knowledge (4 items) & 0.84 & 0.78 & 0.75 \\
Intrinsic motivation to accomplishments (4 & 0.85 & & 0.74 \\
items) & & 0.77 & 0.75 \\
Intrinsic motivation to stimulation (4 items) & 0.86 & 0.80 & 0.75 \\
Introjected motivation (4 items) & 0.84 & 0.75 & 0.76 \\
External regulation (4 items) & 0.83 & 0.61 & 0.75 \\
Identified regulation (4 items) & 0.62 & 0.78 & 0.78 \\
Amotivation (4 items) & 0.85 & & \\
\hline
\end{tabular}

The "Attitude Scale for a Social Studies Course" is developed by Demir \& Akengin (2010). The scale is composed of 26 items with the related information given in Table 4. The scale for 'attitude' towards a Social Studies course is rated in the following way: "Strongly Disagree: 1", "Disagree: 2", "Undecided: 3", "Agree: 4" and "Strongly Agree: 5". Our research also was carried out accordingly. In addition, some negative items in the scale (item 2, item 3, item 4, item 6, item 7 , item 16, item 17, item 18, item 21, item 22, item 23, item 24, item 25 and item 26) were coded reversely.

Table 4

The Reliability of the "Attitude Scale for a Social Studies Course"

\begin{tabular}{lll}
\hline Subscales & $\begin{array}{l}\text { Demir and } \\
\text { Akengin (2010) }\end{array}$ & In this Study \\
\hline Willingness to learn (7 items) & 0.90 & 0.77 \\
Enjoying Social Studies course (8 items) & 0.84 & 0.77 \\
Teacher-related attitudes (6 items) & 0.76 & 0.79 \\
Love of Social Studies (5 items) & 0.72 & 0.82 \\
\hline
\end{tabular}

A semi-structured interview is used for the qualitative part in the research, and it was conducted by the researchers in a face-to-face setting with the students. Qualitative questions were asked after the attitude-scale was completed in order to support the findings obtained from quantitative questions. During the preparation of the semi-structured interview questions, 3 field experts and 1 assessment and evaluation specialist were asked for their opinion. A pilot scheme was performed with three students and a change was made to one question. Accordingly, the questions in the semi-structured interview are:

1. What is your attitude towards the Social Studies course?

2. In addition to this question, "Do you like the Social Studies course or not?" was asked.

3. What motivates you towards the Social Studies course?

In addition to this question, "How does the teacher behavior affect your motivation?" "How do issues affect your motivation?" were asked.

\section{Data Evaluation and Data Display}

Data obtained from the quantitative part of the research was analyzed by SPSS 21. According to Tabachnick \& Fidell (2001), it is more appropriate to consider the pattern of distribution instead of tests of significance for normality in large samplings. Because the standard error will be minor in large samples, it will lead to the rejection of null hypotheses for the tests of significance easily. In 
alignment with other research, to consider the Kolmogorov-Smirnov results as meaningful and/or significant should not be interpreted as excessive deviation from normal distribution. As the sample size increases, the probability of finding small differences is expected to increase (Çokluk, Şekercioğlu \& Büyüköztürk, 2012). Thus, skewness and kurtosis values for the relevant variable were in the range of $-1,+1$, and the tests of significance for skewness and kurtosis values were not found to be significant. The skewness value of the academic motivation scale was,- 412 and the kurtosis value was,- 641 . The skewness value of the scale for attitude towards the Social Studies course was found to be,- 546 and the kurtosis value was found to be -,596. This finding can be considered as evidence that the variable does not excessively deviate from normality. Following the tests for normality, descriptive statistics, correlation, independent samples t-test, oneway ANOVA and Scheffe test were performed. In the research, independent sample test was used to find the effect of the gender variable, ANOVA, descriptive statistics and Scheffe test were used for other variables, and a correlation test was used to find the relationship between the two scales.

In the qualitative part of the current research, data was analyzed through content analysis. Content analysis is a type of qualitative data analysis where data is conceptualized primarily, and then rationally organized according to the emerging concepts, where themes are identified, and data is analyzed in depth (Yıldırım \& Şimşek, 2013). The reason for choosing content analysis is based on the research objective which is to attain a more detailed and comprehensive result for the academic motivation levels and attitudes of secondary school students towards s Social Studies course. The data obtained in this study was first coded (5FS-1..., 6MS-1..., 7MS-1...). The answers given by the participants to each question were assessed individually and then conceptualized. Later, these encodings were organized within a certain logical framework according to their similarities and differences. The data obtained was converted to a table and then interpreted as frequencies and percentages.

Validity and reliability are regarded as the two important criteria for credibility in qualitative research. In this research, validity occurs by explaining the analysis process of the obtained data in detail, and also by including the opinions of secondary school students in the interpretation of findings (Yıldırım \& Şimşek, 2013). To ensure reliability in the current research, investigator triangulation was used. Investigator triangulation is defined as independent analysis of data by two or more researchers, and a comparison of their individual findings occurs with each other (Patton, 2014). In this study, researchers analyzed the qualitative data individually and then compared their findings. A common decision was reached after discussion about issues where the researchers did not have similar views. Furthermore, the categories that were formed by the researchers were also compared and the percentage of agreement was calculated. The percentage of agreement indicates the reliability level in qualitative researches. It is recommended that the percentage of agreement (The percentage of Agreement $=$ Agreement $/$ (Agreement + Disagreement) $\times 100$ ) formulated by Miles and Huberman (1994) is close to $80 \%$. In the current research, the categories formed by the researchers were compared. The same categories were defined as 'agreement' and different categories were defined as 'disagreement'. The calculation for reliability was made separately for each question. With reference 
Faiz, M.; Karasu Avcl, E. (2020). Academic Motivation Levels of Secondary School Students...

to percentage of agreement process, in this study, the percentage of agreement was calculated as $89 \%$.

\section{Findings}

Quantitative and qualitative data are examined separately in this part of the study. The interpretations of the data are given in Tables under the sub-problems.

\section{Findings for Quantitative Part}

In this section of the study, findings for the relationship between the academic motivation levels and attitudes of the participants towards a Social Studies course are included. The student responses to the Motivation scales and Attitudes scales are examined and evaluated in terms of gender, school and grade level variables. The findings obtained are presented in the Tables below.

Abbreviations are used in all Tables. These abbreviations are: IMK for Intrinsic Motivation for Knowledge, IMA for Intrinsic Motivation for Accomplishments, IMS Intrinsic Motivation for Stimulation, ER for External Regulation (ER), IR for Introjected Regulation, IR2 for Identified Regulation, A for Amotivation. WL for Willingness to Learn, ESSC for Enjoying Social Studies Course, TRAS for Teacherrelated Attitudes of Students, and LSS for Love of Social Studies.

Findings for difference by gender in the subscales of participants' academic motivation. For the first sub-problem of the research, the following are examined: the variation by gender in the scores of secondary school students for intrinsic motivation for knowledge; intrinsic motivation for accomplishments; intrinsic motivation for stimulation; introjected regulation; external regulation; identified regulation; and amotivation. Findings obtained from the independent samples Ttest results are shown in Table 5.

Table 5

Independent T-Test Results of Academic Motivation Scale Subscales of Participants' According to Gender

\begin{tabular}{|c|c|c|c|c|c|c|}
\hline Subscales & Gender & $\mathbf{N}$ & Mean & S.S. & $T$ & $\mathbf{p}$ \\
\hline Intrinsic & Female & 220 & 22.71 & 5.16 & \multirow{2}{*}{0.94} & \multirow{2}{*}{0.35} \\
\hline motivation to knowledge & Male & 223 & 22.25 & 5.08 & & \\
\hline Intrinsic motivation- & Female & 220 & 22.23 & 5.04 & \multirow{2}{*}{0.82} & \multirow{2}{*}{0.41} \\
\hline Accomplishments & Male & 223 & 21.82 & 5.30 & & \\
\hline Intrinsic motivation- & Female & 220 & 19.23 & 5.70 & \multirow{2}{*}{0,37} & \multirow{2}{*}{0.71} \\
\hline Stimulation & Male & 223 & 19.03 & 5.52 & & \\
\hline External regulation & Female & 220 & 19.11 & 6.63 & \multirow{2}{*}{-2.42} & \multirow{2}{*}{0.01} \\
\hline & Male & 223 & 20.54 & 5.79 & & \\
\hline Introjected regulation & Female & 220 & 20.49 & 5.06 & \multirow{2}{*}{-1.88} & \multirow{2}{*}{0.06} \\
\hline & Male & 223 & 21.41 & 5.25 & & \\
\hline \multirow[t]{2}{*}{ Identified regulation } & Female & 220 & 24.66 & 4.23 & \multirow{2}{*}{2.46} & \multirow{2}{*}{0.01} \\
\hline & Male & 223 & 23.57 & 5.02 & & \\
\hline \multirow[t]{2}{*}{ Amotivation } & Female & 220 & 25.85 & 3.09 & \multirow{2}{*}{3.67} & \multirow{2}{*}{0.00} \\
\hline & Male & 223 & 24.66 & 3.68 & & \\
\hline \multirow[t]{2}{*}{ All Scale } & Female & 220 & 154.27 & 25.36 & \multirow{2}{*}{0.39} & \multirow{2}{*}{0.69} \\
\hline & Male & 223 & 153.29 & 27.12 & & \\
\hline
\end{tabular}

${ }^{*} \mathrm{p}<, 05$

Table 5 shows the mean of the scores of participants for introjected regulation, it also shows that identified regulation and amotivation varies by gender $(p=0,01$ $p<0,05, p=0,01 p<0,05, p=0,00 p<0,05)$. However, no statistically significant 
difference was found between the scores for intrinsic motivation for knowledge, intrinsic motivation for accomplishments, intrinsic motivation for accomplishments and introjected regulation. The scores of male students were found to be high for external regulation scores. When the scores for identified regulation and amotivation were examined, the scores of female students were found to be high. In other words, the motivation levels of male students are higher in terms of introjected regulation. But, in terms of identified regulation and amotivation scores, the scores of female students are higher. According to this, it can be concluded that female students have less motivation compared to male students.

Findings for difference by school in the subscales of participants' academic motivation. For the second sub-problem of the research, the following are examined: the difference by school in the scores of participants 'for sub-scales. Findings are obtained from the one-way ANOVA test result, and are shown in Table 6.

Table 6

The Results of One-Way Anova of Academic Motivation Scale Subscales of Participants' According to School

\begin{tabular}{|c|c|c|c|c|c|c|c|c|c|c|}
\hline $\begin{array}{l}\text { Subs } \\
\text { cales }\end{array}$ & School & $\mathbf{N}$ & $\bar{X}$ & Ss & $\begin{array}{l}\text { Source } \\
\text { of Var. }\end{array}$ & $\begin{array}{l}\text { Sum of } \\
\text { Squares }\end{array}$ & sd & M.S. & f & $\mathbf{p}$ \\
\hline \multirow[t]{4}{*}{ IMK } & L.L. & 179 & 22.60 & 5.10 & B.G. & 4.50 & 2 & 2.25 & .09 & .92 \\
\hline & I.L & 142 & 22.37 & 5.04 & W.G. & 11595.68 & 440 & 26.35 & & \\
\hline & H.L. & 122 & 22.43 & 5.29 & Total & 11600.18 & 442 & & & \\
\hline & Total & 443 & 22.48 & 5.12 & & & & & & \\
\hline \multirow[t]{4}{*}{ IMA } & L.L. & 179 & 21.84 & 5.11 & B.G. & 21.89 & 2 & 10.94 & .41 & .67 \\
\hline & I.L & 142 & 22.35 & 5.23 & W.G. & 11808.04 & 440 & 26.84 & & \\
\hline & H.L. & 122 & 21.92 & 5.24 & Total & 11829.93 & 442 & & & \\
\hline & Total & 443 & 22.02 & 5.17 & & & & & & \\
\hline \multirow[t]{4}{*}{ IMS } & L.L. & 179 & 19.62 & 5.94 & B.G. & 86.75 & 2 & 43.37 & 1.38 & .25 \\
\hline & I.L & 142 & 18.59 & 5.46 & W.G. & 13797.86 & 440 & 31.36 & & \\
\hline & H.L. & 122 & 19.04 & 5.23 & Total & 13884.61 & 442 & & & \\
\hline & Total & 443 & 19.13 & 5.61 & & & & & & \\
\hline \multirow[t]{4}{*}{ ER } & L.L. & 179 & 19.74 & 6.12 & B.G. & 65.23 & 2 & 32.61 & .83 & .44 \\
\hline & I.L. & 142 & 20.35 & 6.04 & W.G. & 17235.01 & 440 & 39.17 & & \\
\hline & H.L. & 122 & 19.37 & 6.70 & Total & 17300.23 & 442 & & & \\
\hline & Total & 443 & 19.83 & 6.26 & & & & & & \\
\hline \multirow[t]{4}{*}{ IR } & L.L. & 179 & 20.70 & 5.18 & B.G. & 39.51 & 2 & 19.76 & .74 & .48 \\
\hline & I.L & 142 & 21.38 & 5.26 & W.G. & 11758.06 & 440 & 26.72 & & \\
\hline & H.L. & 122 & 20.81 & 5.05 & Total & 11797.57 & 442 & & & \\
\hline & Total & 443 & 20.95 & 5.17 & & & & & & \\
\hline \multirow[t]{4}{*}{ IR2 } & L.L. & 179 & 23.87 & 4.89 & B.G. & 18.14 & 2 & 9.07 & .42 & .66 \\
\hline & I.L & 142 & 24.27 & 4.55 & W.G. & 9613.90 & 440 & 21.85 & & \\
\hline & H.L. & 122 & 24.29 & 4.49 & Total & 9632.04 & 442 & & & \\
\hline & Total & 443 & 24.11 & 4.67 & & & & & & \\
\hline \multirow[t]{4}{*}{ A } & L.L. & 179 & 25.46 & 3.44 & B.G. & 16.10 & 2 & 4.10 & .09 & .91 \\
\hline & I.L & 142 & 25.01 & 3.42 & W.G. & 5230.67 & 440 & 44.20 & & \\
\hline & H.L. & 122 & 25.22 & 3.49 & Total & 5246.77 & 442 & & & \\
\hline & Total & 443 & 25.25 & 3.45 & & & & & & \\
\hline \multirow{4}{*}{$\begin{array}{l}\text { All } \\
\text { Scale }\end{array}$} & L.L. & 179 & 153.83 & 27.37 & B.G. & 100.39 & 2 & 50.20 & .07 & .93 \\
\hline & I.L & 142 & 154.30 & 25.76 & W.G. & 304125.74 & 440 & 691.20 & & \\
\hline & H.L. & 122 & 153.08 & 25.26 & Total & 304226.13 & 442 & & & \\
\hline & Total & 443 & 153.78 & 26.24 & & & & & & \\
\hline
\end{tabular}


Faiz, M.; Karasu Avcl, E. (2020). Academic Motivation Levels of Secondary School Students...

Table 6 shows the results of a descriptive analysis where the participant scores are very close to each other, in terms of the variable of the school where they study. The scores are related to intrinsic motivation for knowledge, intrinsic motivation for accomplishments, intrinsic motivation for stimulation, introjected regulation, and external regulation, identified regulation, and amotivation. Also, the analysis of variance was performed for the participant scores. According to the results of one-way analysis of variance, no difference in scores are found $(f=, 09, p<, 05 ; f=, 41, p<, 05 ; f=1,38, p<, 05, f=, 83, p<, 05, f=, 74, p<, 05, f=, 42, p<, 05$, $f=, 09, p<, 05 ; f=, 07 p<, 05)$. Accordingly, there is no difference between the schools in terms of motivation in any subscales.

Findings for difference by grade level in the subscale's participants' academic motivation. For the third sub-problem of the research, the difference by grade level in the participant scores for sub-scales are examined. Findings obtained from the one-way ANOVA test result are shown in Table 7.

Table 7

One-Way Anova Results of Academic Motivation Scale Subscales of Participants' According to Grade Level

\begin{tabular}{|c|c|c|c|c|c|c|c|c|c|c|}
\hline $\begin{array}{l}\text { Subs } \\
\text { cales }\end{array}$ & Grade & $\mathbf{N}$ & $\overline{\mathbf{X}}$ & Ss & $\begin{array}{l}\text { Source } \\
\text { of Var. }\end{array}$ & $\begin{array}{l}\text { Sum of } \\
\text { Squares }\end{array}$ & sd & M.S. & $f$ & $p$ \\
\hline \multirow[t]{4}{*}{ IMK } & 5 & 97 & 23.79 & 4.61 & B.G. & 212.25 & 2 & \multirow{4}{*}{$\begin{array}{l}106.13 \\
25.88\end{array}$} & \multirow[t]{4}{*}{4.10} & \multirow[t]{4}{*}{.01} \\
\hline & 6 & 199 & 22.16 & 5.30 & W.G. & 11387.93 & 440 & & & \\
\hline & 7 & 147 & 22.06 & 5.10 & Total & 11600.18 & 442 & & & \\
\hline & Total & 443 & 22.48 & 5.12 & & & & & & \\
\hline \multirow[t]{4}{*}{ IMA } & 5 & 97 & 23.32 & 5.03 & B.G. & 208.21 & 2 & \multirow{4}{*}{$\begin{array}{l}104.11 \\
26.41\end{array}$} & \multirow[t]{4}{*}{3.94} & \multirow[t]{4}{*}{.02} \\
\hline & 6 & 199 & 21.63 & 5.13 & W.G. & 11621.72 & 440 & & & \\
\hline & 7 & 147 & 21.70 & 5.23 & Total & 11829.93 & 442 & & & \\
\hline & Total & 443 & 22.02 & 5.17 & & & & & & \\
\hline \multirow[t]{4}{*}{ IMS } & 5 & 97 & 20.13 & 5.85 & B.G. & 140.43 & 2 & \multirow{4}{*}{$\begin{array}{l}70.21 \\
31.24\end{array}$} & \multirow[t]{4}{*}{2.25} & \multirow[t]{4}{*}{.11} \\
\hline & 6 & 199 & 18.67 & 5.39 & W.G. & 13744.18 & 440 & & & \\
\hline & 7 & 147 & 19.09 & 5.68 & Total & 13884.61 & 442 & & & \\
\hline & Total & 443 & 19.13 & 5.61 & & & & & & \\
\hline \multirow[t]{4}{*}{ ER } & 5 & 97 & 20.50 & 6.15 & B.G. & 65.32 & 2 & \multirow{4}{*}{$\begin{array}{l}32.66 \\
39.17\end{array}$} & \multirow[t]{4}{*}{.83} & \multirow[t]{4}{*}{.44} \\
\hline & 6 & 199 & 19.50 & 6.44 & W.G. & 17234.91 & 440 & & & \\
\hline & 7 & 147 & 19.84 & 6.08 & Total & 17300.23 & 442 & & & \\
\hline & Total & 443 & 19.83 & 6.26 & & & & & & \\
\hline \multirow[t]{4}{*}{ IR } & 5 & 97 & 20.96 & 5.42 & B.G. & 46.04 & 2 & \multirow{4}{*}{$\begin{array}{l}23.02 \\
26.71\end{array}$} & \multirow[t]{4}{*}{0.86} & \multirow[t]{4}{*}{.42} \\
\hline & 6 & 199 & 20.64 & 5.26 & W.G. & 11751.53 & 440 & & & \\
\hline & 7 & 147 & 21.37 & 4.86 & Total & 11797.57 & 442 & & & \\
\hline & Total & 443 & 20.95 & 5.17 & & & & & & \\
\hline \multirow[t]{4}{*}{ IR2 } & 5 & 97 & 24.30 & 4.92 & B.G. & 61.01 & 2 & \multirow{4}{*}{$\begin{array}{l}30.51 \\
21.75\end{array}$} & \multirow[t]{4}{*}{1.40} & \multirow[t]{4}{*}{.25} \\
\hline & 6 & 199 & 23.71 & 4.75 & W.G. & 9571.02 & 440 & & & \\
\hline & 7 & 147 & 24.53 & 4.37 & Total & 9632.04 & 442 & & & \\
\hline & Total & 443 & 24.11 & 4.67 & & & & & & \\
\hline \multirow[t]{4}{*}{ A } & 5 & 97 & 25.31 & 3.62 & B.G. & .94 & 2 & \multirow{4}{*}{$\begin{array}{l}0.47 \\
11.92\end{array}$} & \multirow[t]{4}{*}{0.04} & .96 \\
\hline & 6 & 199 & 25.26 & 3.28 & W.G. & 5245.82 & 440 & & & \\
\hline & 7 & 147 & 25.18 & 3.57 & Total & 5246.76 & 442 & & & \\
\hline & Total & 443 & 25.25 & 3.45 & & & & & & \\
\hline All & 5 & 97 & 158.30 & 26.65 & B.G. & 2960.73 & 2 & $\begin{array}{l}1480.3 \\
7\end{array}$ & 2.16 & .12 \\
\hline Scale & 6 & 199 & 151.56 & 26.25 & W.G. & 301265.40 & 440 & 684.69 & & \\
\hline & 7 & 147 & 153.79 & 25.72 & Total & 304226.13 & 442 & & & \\
\hline & Total & 443 & 153.78 & 26.24 & & & & & & \\
\hline
\end{tabular}


Table 7 shows the results of the descriptive analysis. A statistically significant difference in the participant scores in terms of the grade level variable is evident for: intrinsic motivation for knowledge; intrinsic motivation for accomplishments; intrinsic motivation for stimulation; introjected regulation; external regulation; identified regulation, and amotivation. Also, for the secondary school students an analysis of variance is performed for their scores. According to the results of a one-way analysis of variance, there is a difference between the scores of intrinsic motivation for knowledge and intrinsic motivation for accomplishments $(f=4,10$, $p<, 05 ; f=3,94, p<, 05 ; f=2,25, p<, 05, f=, 83, p<, 05, f=, 86, p<, 05, f=1,40, p<, 05, f=, 04$, $p<, 05 ; f=2,16 p<, 05)$.

A Scheffe test is used to compare the participant scores for intrinsic motivation to knowledge and intrinsic motivation for accomplishments in terms of grade level variable. Relevant findings are shown in Table 8.

Table 8

Scheffe Test Comparison Results of Academic Motivation Scale Subscales According to Grade Level of Participants

\begin{tabular}{lccccc}
\hline Subscales & Mean Difference & Std. Error & $\mathbf{p}$ & \multicolumn{2}{c}{ Difference } \\
\hline Intrinsic motivation to & 1.63 & .63 & .036 & 5 & 6 \\
knowledge & 1.73 & .67 & .036 & 5 & 7 \\
Intrinsic motivation- & 1.69 & .31 & .031 & 5 & 6 \\
Accomplishments & & & & & \\
\hline
\end{tabular}

Table 8 shows a significant difference between students in Grades 5 and 6 , and also in Grades 5 and 7 in terms of their scores for intrinsic motivation for knowledge, in favor of the 5 th graders. A significant difference is found between Grades 5 and 6 for intrinsic motivation for accomplishment scores, in favor of the 5th graders. According to this, it can be said that there is a decrease in motivation as the grade level increases.

Findings for difference by gender in the subscales of participants' attitudes towards social studies. For the fourth sub-problem of the research, the variation by gender in the participant scores occurs for total score: Willingness to Learn, Enjoying Social Studies course, Teacher-Related Attitudes, and Love of Social Studies. Findings obtained from the independent samples T-Test result are shown in Table 9.

Table 9

Independent T-Test Results of Social Studies Attitude Scale Subscales of Participants According to Gender

\begin{tabular}{|c|c|c|c|c|c|c|}
\hline Subscales & Gender & $\mathbf{N}$ & $\mathbf{X}$ & Ss & $t$ & $p$ \\
\hline \multirow[t]{2}{*}{ Willingness to Learn } & Female & 220 & 25.83 & 7.50 & \multirow[t]{2}{*}{11} & \multirow[t]{2}{*}{0,91} \\
\hline & Male & 223 & 25.76 & 7.20 & & \\
\hline Enjoying Social & Female & 220 & 27.94 & 8.62 & \multirow[t]{2}{*}{,- 19} & \multirow[t]{2}{*}{0,84} \\
\hline Studies Course & Male & 223 & 28.09 & 7.75 & & \\
\hline \multirow{2}{*}{$\begin{array}{l}\text { Teacher-related attitudes of } \\
\text { students }\end{array}$} & Female & 220 & 23.83 & 6.09 & \multirow[t]{2}{*}{0,68} & \multirow[t]{2}{*}{49} \\
\hline & Male & 223 & 23.44 & 5.77 & & \\
\hline \multirow[t]{2}{*}{ Love of Social Studies } & Female & 220 & 19.32 & 5.21 & \multirow[t]{2}{*}{$-0,05$} & \multirow[t]{2}{*}{96} \\
\hline & Male & 223 & 19.34 & 4.93 & & \\
\hline \multirow[t]{2}{*}{ All Scale } & Female & 220 & 96.92 & 96.92 & \multirow[t]{2}{*}{.13} & \multirow[t]{2}{*}{.89} \\
\hline & Male & 223 & 96.64 & 22.23 & & \\
\hline
\end{tabular}


Faiz, M.; Karasu Avcl, E. (2020). Academic Motivation Levels of Secondary School Students...

$* \mathrm{p}<, 05$

For Table 9 the mean of the scores of secondary school students do not vary by gender for willingness to learn, enjoying the social studies course, teacherrelated attitudes, and love of social studies $(p=0,91 p<0,05, p=, 84 p<0,05, p=, 49$ $p<0,05 ; p=, 96 p<0,05 ; p=, 89 p<0,05)$. Accordingly, it can be said that the gender variable does not have an effect on the attitudes of secondary school students towards the Social Studies course.

Findings for difference by school in the subscales of participants' attitudes towards social studies. For the fifth sub-problem of the research, the following are examined: the variation by school in the scores of secondary school students for Willingness to Learn, Enjoying Social Studies course, Teacher-Related Attitudes and Love of Social Studies. Findings obtained from the one-way ANOVA test result are shown in Table 10.

Table 10

One-Way Anova Results of Participants' Social Studies Attitude Scale Subscales According to School

\begin{tabular}{lcccccccccc}
\hline $\begin{array}{l}\text { Subs } \\
\text { cales }\end{array}$ & School & $\mathrm{N}$ & $\overline{\mathbf{x}}$ & $\mathrm{Ss}$ & $\begin{array}{c}\text { Source } \\
\text { of Var. }\end{array}$ & $\begin{array}{c}\text { Sum of } \\
\text { Squares }\end{array}$ & sd & M.S. & $\mathrm{f}$ & $\mathrm{P}$ \\
\hline \multirow{6}{*}{ WL } & L.L. & 179 & 27.21 & 6.76 & B.G. & 643.17 & 2 & 321.59 & 6.10 & .00 \\
& I.L & 142 & 25.22 & 7.64 & W.G. & 23196.17 & 440 & 52.72 & & \\
& H.L. & 122 & 24.40 & 7.52 & Total & 23839.34 & 442 & & & \\
& Total & 443 & 25.80 & 7.34 & & & & & & \\
& L.L. & 179 & 29.33 & 7.88 & B.G. & 582.48 & 2 & 291.24 & 4.41 & .01 \\
ESSC & I.L & 142 & 27.60 & 8.66 & W.G. & 29034.42 & 440 & 65.99 & & \\
& H.L. & 122 & 26.58 & 7.81 & Total & 29616.90 & 442 & & & \\
& Total & 443 & 28.02 & 8.19 & & & & & & \\
& L.L. & 179 & 24.35 & 5.48 & B.G. & 298.45 & 2 & 149.23 & 4.31 & .01 \\
TRAS & I.L & 142 & 23.84 & 5.83 & W.G. & 15219.61 & 440 & 34.59 & & \\
& H.L. & 122 & 22.35 & 6.48 & Total & 15518.06 & 442 & & & \\
& Total & 443 & 23.64 & 5.93 & & & & & & \\
& L.L. & 179 & 19.78 & 4.83 & B.G. & 136.50 & 2 & 68.25 & 2.68 & .07 \\
LSS & I.L & 142 & 19.52 & 5.03 & W.G. & 11195.58 & 440 & 25.44 & & \\
& H.L. & 122 & 18.45 & 5.36 & Total & 11332.07 & 442 & & & \\
& Total & 443 & 19.33 & 5.06 & & & & & & \\
All & L.L. & 179 & 100.70 & 21.85 & B.G. & 5803.90 & 2 & 2901.9 & 5.64 & .00 \\
Scale & I.L & 142 & 96.18 & 22.98 & W.G. & 226187.87 & 440 & 514.06 & & \\
& H.L. & 122 & 91.78 & 23.48 & Total & 231991.77 & 442 & & & \\
& Total & 443 & 96.78 & 22.91 & & & & & & \\
\hline
\end{tabular}

$* \mathrm{p}<, 05$

Table 10 shows the results of a descriptive analysis, and a statistically significant difference in the participant scores for the school variable occurs for total score, willingness to learn, enjoying social studies course, teacher-related attitudes, and love of social studies. Also, the analysis of variance was performed for the participant scores. According to the results from a one-way analysis of variance, a significant difference between the scores occurs for all subscales: willingness to learn, enjoying Social Studies course and teacher-related attitudes $(f=6,10$, $p<, 05 ; f=4,41, p<, 05 ; f=4,31, p<, 05, f=2,68, p<, 05 ; f=5,64 p<, 05)$.

A Scheffe test is used to compare the participant scores in grade level variable for the total score of knowing about the subject, Willingness to Learn, Enjoying 
Social Studies course, and Teacher-Related Attitudes. Relevant findings are given in Table 11.

Table 11

Scheffe Test Comparison Results of Graderoom Variables of Social Studies Attitude Scale Subscales of Participants

\begin{tabular}{llllll}
\hline Subscales & Mean Difference & Std. Error & $\mathbf{p}$ & \multicolumn{2}{l}{ Difference } \\
\hline Willingness to learn & 2.81 & .85 & .00 & L.L. & H.L. \\
Enjoying Social Studies Course & 2.75 & .95 & .02 & L.L. & H.L. \\
Attitudes from the teacher & 1.99 & .69 & .02 & L.L. & H.L. \\
All Scale & 8.88 & 2,66 & .00 & L.L. & H.L. \\
\hline
\end{tabular}

${ }^{*} \mathrm{p}<, 05$

Table 11 shows a significant difference between low level socio-economic status and high-level economic status schools in the scores for willingness to learn, enjoying Social Studies course and teacher-related attitudes, in favor of low-level socio-economic status school. According to this, it can be said that the students who study at low level socio-economic status school have more positive attitude towards the Social Studies course.

Findings for difference by grade level in the subscales of participants' attitudes towards social studies. For the sixth sub-problem of the research, the following were examined: variation by grade level in the scores of participants for Willingness to Learn, Enjoying Social Studies course, Teacher-Related Attitudes, and Love of Social Studies. Findings obtained from the one-way ANOVA test result are shown in Table 12:

Table 12

One-Way ANOVA Results of Participants' Social Studies Attitude Scale Subscales According to Grade Level

\begin{tabular}{lllllllllll}
\hline $\begin{array}{l}\text { Subs } \\
\text { cales }\end{array}$ & Grade & $\mathbf{N}$ & $\overline{\mathbf{x}}$ & Ss & $\begin{array}{l}\text { Source } \\
\text { of Var. }\end{array}$ & $\begin{array}{l}\text { Sum of } \\
\text { Squares }\end{array}$ & Sd & M. S. & $\mathbf{f}$ & $\mathbf{p}$ \\
\hline \multirow{4}{*}{ WL } & 5 & 97 & 25.76 & 7.34 & B.G. & 202.88 & 2 & 101.44 & 1.89 & .15 \\
& 6 & 199 & 25.15 & 7.49 & W.G. & 23636.45 & 440 & 53.72 & & \\
& 7 & 147 & 26.7 & 7.10 & Total & 23839.34 & 442 & & & \\
& Total & 443 & 25.8 & 7.34 & & & & & & \\
& 5 & 97 & 27.8 & 8.65 & B.G. & 131.97 & 2 & 65.99 & .99 & .37 \\
ESSC & 6 & 199 & 27.56 & 8.00 & W.G. & 29484.93 & 440 & 67.01 & & \\
& 7 & 147 & 28.78 & 8.13 & Total & 29616.90 & 442 & & & \\
& Total & 443 & 28.02 & 8.19 & & & & & & \\
& 5 & 97 & 23.39 & 6.09 & B.G. & 120.62 & 2 & 60.31 & 1.72 & .18 \\
TRAS & 6 & 199 & 23.21 & 6.06 & W.G. & 15397.43 & 440 & 34.99 & & \\
& 7 & 147 & 24.37 & 5.60 & Total & 15518.06 & 442 & & & \\
& Total & 443 & 23.64 & 5.93 & & & & & & \\
& 5 & 97 & 19.4 & 5.15 & B.G. & 136.77 & 2 & 68.38 & 2.69 & .07 \\
LSS & 6 & 199 & 18.77 & 5.33 & W.G. & 11195.31 & 440 & 25.44 & & \\
& 7 & 147 & 20.03 & 4.54 & Total & 11332.07 & 442 & & & \\
& Total & 443 & 19.33 & 5.06 & & & & & & \\
All & 5 & 97 & 96.35 & 23.30 & B.G. & 2305.50 & 2 & 1152.75 & 2.21 & .11 \\
Scale & 6 & 199 & 94.69 & 23.47 & W.G. & 229686.27 & 440 & 522.01 & & \\
& 7 & 147 & 99.89 & 21.66 & Total & 231991.77 & 442 & & & \\
\hline
\end{tabular}

$* \mathrm{p}<, 05$ 
Faiz, M.: Karasu Avcı, E. (2020). Academic Motivation Levels of Secondary School Students...

Table 12 shows the results of descriptive analysis, and the participant scores are very close to each other in terms of grade level variable for willingness to learn, enjoying social studies course, teacher-related attitudes and love of social studies. Also, the analysis of variance was performed for the participant scores. According to the results of one-way analysis of variance, no difference was found $(f=1,89, p<, 05 ; f=, 99, p<, 05 ; f=1,72, p<, 05, f=2,69, p<, 05 ; f=2,21 p<, 05)$. So, there is no variation by grade level in all subscales.

Findings for arithmetic mean, standard deviation and correlation of participants' academic motivation scale and attitude scale for social studies. Table 13 shows the findings of participant scores for the arithmetic mean, standard deviation and correlation of the academic motivation scale and attitude scale for the Social Studies course.

Table 13

Arithmetic Mean, Standard Deviation and Correlation Values of Variables

\begin{tabular}{lcccc}
\hline Subscales & $\overline{\mathbf{X}}$ & Ss & $\mathbf{1}$ & $\mathbf{2}$ \\
\hline 1.Academic Motivation & 150.96 & 26.89 & 1 & .57 \\
2.Social Studies Attitudes & 96.78 & 22.91 & & 1 \\
\hline
\end{tabular}

In Table 1 1, when the relationship between academic motivation and attitude scale for the Social Studies course is examined, it is determined that there is a mid-level positive relationship between the academic motivation levels and attitudes of participants towards Social Studies course. In other words, as the academic motivation increases, the attitude to Social Studies course improves at a medium level.

Findings for arithmetic mean, standard deviation and correlation in the subscales of participants' academic motivation. Table 14 shows the findings for the arithmetic mean, standard deviation and correlation of the intrinsic motivation for knowledge, intrinsic motivation for accomplishments, intrinsic motivation for stimulation, introjected regulation, external regulation, identified regulation and amotivation variables.

Table 14

Arithmetic Mean, Standard Deviation and Correlation Values of Variables

\begin{tabular}{lccccccccc}
\hline Subscales & $\mathbf{X}$ & Ss & $\mathbf{1}$ & $\mathbf{2}$ & $\mathbf{3}$ & $\mathbf{4}$ & $\mathbf{5}$ & $\mathbf{6}$ & $\mathbf{7}$ \\
\hline $\begin{array}{l}\text { 1.Intrinsic motivation to } \\
\text { knowledge }\end{array}$ & 22.48 & 5.12 & 1 & .57 & .65 & .45 & .45 & .62 & .29 \\
$\begin{array}{l}\text { 2.Intrinsic motivation- } \\
\text { accomplishments }\end{array}$ & 22.02 & 5.17 & & 1 & .60 & .54 & .50 & .58 & .29 \\
$\begin{array}{l}\text { 3.Intrinsic motivation- } \\
\text { stimulation }\end{array}$ & 19.13 & 5.61 & & & 1 & .49 & .35 & .43 & .09 \\
$\begin{array}{l}\text { 4.External regulation } \\
\text { 5.Introjected regulation }\end{array}$ & 19.83 & 6.26 & & & & 1 & .54 & .41 & .17 \\
6.Identified regulation & 20.95 & 5.17 & & & & & 1 & .49 & .24 \\
7.Amotivation & 24.11 & 4.67 & & & & & 1 & .45 \\
\hline
\end{tabular}

When the relationship between the subscales in Table 14 are considered, it was determined that a high-level positive relationship occurs between the subscale for intrinsic motivation for knowledge and intrinsic motivation for stimulation and identified regulation sub-scales. It was also found that there was a mid-level positive relationship between the sub-scales for intrinsic motivation 
for knowledge, introjected regulation, and external regulation subscales. Additionally, a low-level positive relationship exists between the intrinsic motivation for knowledge and amotivation subscales.

A mid-level positive relation was found between the intrinsic motivation for accomplishments, the introjected regulation subscales, the external regulation, and identified regulation sub-scales. A mid-level positive relation also was found between the subscale for intrinsic motivation for stimulation and introjected regulation and identified regulation subscales. No relationship was determined between the intrinsic motivation for stimulation and amotivation sub-scales. A mid-level positive relationship was found between external regulation and the identified regulation sub-scales; however, low-level positive relationships are not found between these two and the amotivation sub-scale. A mid-level positive relation is determined between the identified regulation and amotivation subscales.

Findings for arithmetic mean, standard deviation and correlation in the subscales of participants' attitudes for social studies. Table 15 shows the research findings for the arithmetic mean, standard deviation and correlation of the variables for Willingness to Learn, Enjoying Social Studies course, Teacher-Related Attitudes and Love of Social Studies.

Table 15

Arithmetic Mean, Standard Deviation and Correlation Values of Variables

\begin{tabular}{lllllll}
\hline Subscales & $\overline{\mathbf{X}}$ & Ss & $\mathbf{1}$ & $\mathbf{2}$ & $\mathbf{3}$ & $\mathbf{4}$ \\
\hline 1.Willingness to Learn & 25.79 & 7.344 & 1 & .74 & .71 & .67 \\
2.Enjoying Social Studies Course & 28.01 & 8.185 & & 1 & .59 & .49 \\
3.Attitudes from the teacher & 23.63 & 5.925 & & & 1 & .75 \\
4.Love of Social Studies & 19.32 & 5.063 & & & 1 \\
\hline
\end{tabular}

A high-level positive relationship exists between the sub-scales for willingness to learn and enjoying Social Studies course, teacher-related attitudes and love of social studies. A mid-level positive relation is found between the sub-scales for enjoying Social Studies course and teacher-related attitudes and love of Social Studies. A high-level positive relationship exists between the teacher-related attitudes and love of Social Studies sub-scales.

\section{Findings for Qualitative Part}

The following section shows the findings of the qualitative part of the study.

Findings for participants' attitudes towards social studies course. Table 16 shows the findings for the participant opinions about the sub-problem "What is your attitude towards Social Studies course?

Table 16

Statistical Data Regarding Attitudes of Participants on Social Studies Course

\begin{tabular}{lllll}
\hline Grade Level & Positive Attitude & \multicolumn{2}{l}{ Negative Attitude } \\
\hline & $\mathrm{f}$ & $\%$ & $\mathrm{f}$ & $\%$ \\
5th grade & 12 & 33.33 & 3 & 33.33 \\
6th grade & 10 & 27.77 & 5 & 55.55 \\
7th grade & 14 & 38.88 & 1 & 11.11 \\
Total & 36 & 100 & 9 & 100 \\
\hline
\end{tabular}


Faiz, M.; Karasu Avcl, E. (2020). Academic Motivation Levels of Secondary School Students...

Table 16 shows the attitudes of participants towards the Social Studies course. While students $(f=36)$ state that they have positive attitudes towards the Social Studies course, the students $(f=9)$ do have negative attitudes. When student attitudes are examined at the grade level variable, it is seen that 5 th grade students $(f=12)$ have positive attitudes towards the Social Studies course but some $(\mathrm{f}=3)$ have negative attitudes. While the 6th grade students $(\mathrm{f}=10)$ have positive attitudes towards the Social Studies course, there are students ( $f=5)$ who have negative attitudes. 7 th grade students $(f=14)$ have positive attitudes and only a small number $(\mathrm{f}=1)$ have negative attitudes towards the course. Generally, the 7th grade students display more positive attitudes towards the Social Studies course; however, the 6th grade students have fewer positive attitudes to the course, when compared to the other grade levels. The opinions of some students who state both positive and negative attitudes in response to this research question are directly given below:

5MS-7 "In my opinion, Social Studies is a nice and fun lesson. I enjoy learning something about history in this course."

5MS-11 "I think this is a nice course. I like the course subjects."

7FS-13 "I love Social Studies much. It teaches new things to me. I get good marks in the exams."

Students who have positive attitudes towards Social Studies course find it entertaining and like it. They are interested in the subjects of a Social Studies course. Furthermore, students state that they get high marks in the courses which is also a contributing factor to their positive attitude. Therefore, it can be said that attitudes of the students are influenced by their interest in the course, together with finding the course entertaining, and from receiving high marks. Such findings can be associated with the sub-scales for Enjoying Social Studies course and Love of Social Studies, which are also included in the quantitative part of the study.

5MS-10 "I do not like Social Studies much. In this course, some topics like the lonians are better not to be dealt with. No exams. Let's write less."

6MS-11 "I think Social Studies course should be dropped. Other courses should be added, instead of it."

6MS-14 "It could be more interesting for me if the history of football was taught in Social Studies course. Sometimes, I think that I can enjoy this course if we go out during the course."

Students who have negative attitudes towards Social Studies course express that they do not like some topics to be taught in the courses, and that this course should not be included in the curriculum because other subjects are more interesting. There are also students who do not want to take exams for this course. This can be explained by the failure of students to do well in the exams for Social Studies course.

Findings for factors motivating participants to social studies course. Findings for the opinions of participants as related to the sub-problem in the research "What does motivate you towards the Social Studies course?" are presented in Table 17. 
Table 17

Statistical Data on the Opinions of the Participants about the Factors That Motivate Towards the Social Studies Course

\begin{tabular}{lll}
\hline Opinions & $\mathbf{f}$ & \% \\
\hline Teachers to be fun teachers & 14 & 16.8 \\
The course includes topics related to history & 12 & 14.4 \\
The topics are remarkable & 12 & 14.4 \\
Teacher's style of instruction & 11 & 13.2 \\
Teacher's character & 7 & 8.4 \\
Love the teacher and agree with the teacher & 5 & 6.02 \\
The use of visuals in the course & 5 & 6.02 \\
Watching movies in the course & 3 & 3.6 \\
Playing games in course & 2 & 2.4 \\
Class arrangement & 1 & 1.2 \\
Explaining Atatürk in the course & 1 & 1.2 \\
Getting high marks & 1 & 1.2 \\
Easy questions & 1 & 1.2 \\
Easy and fun topics & 1 & 1.2 \\
The course includes topics related environmental pollution & 1 & 1.2 \\
The course includes topics related culture & 1 & 1.2 \\
Make an activity in class & 1 & 1.2 \\
Love the course & 1 & 1.2 \\
Win prizes & 1 & 1.2 \\
Skip to last topic & 1 & 1.2 \\
Story telling & 1 & 1.2 \\
Total & 83 & 100 \\
\hline
\end{tabular}

Table 17 shows the factors that motivate students towards the Social Studies course. Students provided a range of answers to this question. From the student responses the following was demonstrated: The most motivating factor was the "Teacher's being entertaining" ( $f=14$, Female=9, Male=5). Students also stated, respectively, that "Handling the subjects related to history in the course" $(f=12$, Female $=3$, Male=12), "Dealing with attention-grabbing course subjects" $(\mathrm{f}=12$, Female $=4$, Male $=8$ ) and "Teacher's way of teaching the subject" ( $f=11$, Female=9, Male=2) also motivate them towards the course. The opinions of some students, related to this question of the research, are directly given below.

5 MS-5 "Our teacher gives the lecture very well; the course is not boring; the teacher is entertaining. We watch historical movies."

5MS-7 "The teacher gives the course by walking around us in the class and this makes me motivated to the course. Also, I like to learn through slides."

6MS-1"Our teacher's explaining well makes us feel motivated. Sometimes, jokes during the course and watching movies also motivate me to the course."

6MS-10 "Learning about the past in Social Studies courses motivates me to the course. Learning our rights and responsibilities and also our teacher's being entertaining make me feel motivated."

7FS-9 "I am happy to learn subjects such as the people who lived in the past, the challenges they faced with, the principalities they founded, and etc. Our love for the teacher also affects our love of the course".

Students explained the factors that motivate them towards Social Studies course as generally being subject-oriented and teacher-related. In addition, the factors that motivate students towards the Social Studies course were found to be related to the subjects about history in the course, the interesting nature of 
Faiz, M.; Karasu Avcl, E. (2020). Academic Motivation Levels of Secondary School Students...

the subjects, and the way of teaching the course. When the factors motivating students to Social Studies course are examined, it can be said that students are influenced by both intrinsic and extrinsic motivation factors.

\section{Result \& Discussion}

Academic motivation levels and attitude are important to accomplishing the objectives of the Social Studies course. If students have academic motivation and display positive attitudes towards the Social Studies course, this will also have an effect on their academic success within the course. The academic achievement of the student will also increase if they have high levels of motivation and a positive attitude towards the course. In this section, the results obtained from the research are discussed as based on the literature review.

In the study, motivation levels of the secondary school students were examined according to gender. A significant difference in the mean of the scores for introjected regulation, identified regulation and amotivation subscales were determined by the gender variable. The differences were found to be significant in favor of male students for introjected regulation; and the differences were in favor of female students in the scores for identified regulation and amotivation. While no differences were seen in the study carried out by Canbay (2016), Türk (2018) and Seyis (2011), a significant difference between gender variables and the sub-scales of academic motivation levels were found in the study by Taşkın (2015). From the results of those studies, a difference in the Amotivation levels of male pre-service teachers was found, and a difference in favor of female pre-service teachers was found for intrinsic and extrinsic motivation. In the study carried out by Gömleksiz \& Serhatoğlu (2013), there was a significant difference in favor of male students for Amotivation and in favor of female students for extrinsic motivation.

Çakır (2006) and Eryüksel (1996) indicated that there was a difference, in favor of female students, in the sub-scale for extrinsic motivation. Yavuz (2014) concluded that the levels of intrinsic motivation amongst female students were higher than those of male students. Yöyen (2008) determined that the relationship between academic motivation levels and gender variables were statistically significant in favor of females. Akbaşlı, Kubilay and Durnalı (2017) found that female participants possessed higher levels of extrinsic motivation compared to male participants. According to this, it can be said that the results of studies from the literature are consistent with the results of this research. It can be concluded that the motivation levels of both male and female students are influenced more by external factors, and that female students have less motivation.

In the current study, the motivation levels of secondary school students were examined according to the school where they study. It is understood from the findings that the scores of secondary school students are very close to each other in terms of school variable for intrinsic motivation for knowledge, intrinsic motivation for accomplishments, intrinsic motivation for stimulation, introjected regulation, external regulation, identified regulation, and amotivation. In other words, no variation was observed. Aytaç (2006) and Çakır (2006) determined no significant difference to occur in the motivation level scores of students in their study according to the level of family income. The results of such studies from the 
literature are similar to the findings emerging from the current research. In the study carried out by Seyis (2011), it was determined that students with high socioeconomic status had high levels of motivation.

On the other hand, Yavuz (2006) determined that students who were receiving education in a public school had higher levels of motivation than the ones studying at a private school. The results of these studies in the literature are not consistent with the findings in this research. Accordingly, it can be concluded that students are not influenced by the socio-economic status.

In the current study, the motivation levels of secondary school students were examined according to grade level. It is realized that the scores of secondary school students vary by grade level for intrinsic motivation for knowledge, intrinsic motivation for accomplishments, intrinsic motivation for stimulation, introjected regulation, external regulation, identified regulation and amotivation. The difference between the scores for intrinsic motivation for knowledge is in favor of the 5th grade students, between Grades 5 and 6 and Grades 5 and 7. Also, in the scores for intrinsic motivation for accomplishments, a significant difference between the scores from students in Grades 5 and 6 was found to occur in favor of the 5th grade students. In the study by Türk (2018), a difference was found in the scores for intrinsic motivation for knowledge between students in Grades 6 and 7, and it was determined that the difference was in favor of the 7th grade students. In these studies, from the literature (Akbaşlı, Kubilay \& Durnalı, 2017; Çakır, 2006; Karagöz-Bolat, 2007; Köse, 2010; Seyis, 2011), it is seen that students at a low-grade level have higher motivation than the students at higher grade levels. The results of these studies are consistent with the findings obtained from this research. With increasing age and advancing grade level, children confront the teenage problems and conflicts with school. This mostly leads students to focus on these problems and conflicts, and as a result, decreases their motivation towards school (Kulaksızoğlu, 2004: 18). However, there are some studies revealing that the grade and motivation levels increase in parallel (Canbay, 2016; Taşkın, 2015; Türk, 2018) Drawing on findings from this research and from studies in the literature, it can be concluded that motivation levels increase when the grade level is lower.

In the current study, the attitudes of secondary school students to Social Studies course were examined according to gender variables. It is seen that the mean of the scores of secondary school students does not vary by gender for willingness to learn, enjoying Social Studies course, teacher-related attitudes and love of Social Studies. In the studies by Demir (2010), Ergin (2006), Oğur (2009), Öztürk \& Baysal (1999), Sidekli (2010), Yılmazer and Demir (2014), it was also concluded that no significant difference by gender was found. These studies are also consistent with the result of this research. However, there are studies to indicate that female students develop more positive attitudes than male students (Altıntaş, 2005; Tay \& Akyürek Tay, 2006), and male students have developed more positive attitudes than female students (Çelen, 2014).

In the current study, the attitudes of secondary school students towards a Social Studies course were examined according to school variables. The scores vary by school for the total score, willingness to learn, enjoying Social Studies course, teacher-related attitudes and love of Social Studies. Among the scores for willingness to learn, enjoying Social Studies course and teacher-related 
attitudes, there was a significant difference between low level socio-economic school and high-level socio-economic schools in favor of low-level socioeconomic school. According to this, the attitude of students at the school with low socio-economic status is higher. The studies carried out by Altıntaş $(2005)$ and Demir (2010) are consistent with the result of this research. Oğur (2009), on the other hand, reached a conclusion contrary to the finding obtained in this study. It was concluded that the attitudes of students towards a Social Studies course improved as the level of family income increased. But no difference was found in the study by Yllmazer \& Demir (2014). As a result, it can be stated that the students receiving education at low socio-economic status school have more positive attitude towards Social Studies course. In other words, it can be concluded that the students with low socio-economic status had higher level of attitudes.

Another variable in the research is grade level. The scores of secondary school students for willingness to learn, enjoying Social Studies course, teacher-related attitudes and love of Social Studies are very close to each other in terms of grade level variable. Yllmazer \& Demir (2014) did not find a difference according to grade level. The result of this study shows similarity with this research. Demir (2010) concluded that 6th grade students had higher scores for their attitudes towards a Social Studies course in comparison with the 7th grade students. Ergin (2006) and Öztürk \& Baysal (1999) concluded that the 4th grade students had higher attitude scores compared to the 5th grade students. Oğur (2009) determined that the 7th grade students had higher scores for their attitudes towards a Social Studies course in comparison with the 6th grade students.

When the relationship between the two scales in the study was examined, a high-level positive relationship was shown between the academic motivation levels of secondary school students and their attitudes towards the Social Studies course. It can be stated that motivation levels also increase with an increase in attitude. Considering the relationship between the sub-scales in the Motivation Scale, the following findings are revealed; a high-level positive relationship exists between the sub-scale for intrinsic motivation for knowledge and intrinsic motivation for stimulation, and identified regulation; a mid-level positive relationship occurs between the sub-scales of intrinsic motivation for knowledge and introjected regulation, and external regulation; and a low-level positive relationship exists between the subscales of intrinsic motivation for knowledge and amotivation.

A mid-level positive relationship was found between the sub-scale of intrinsic motivation for accomplishments and introjected regulation, external regulation, and identified regulation. A mid-level positive relationship occurs between the sub-scales of intrinsic motivation for stimulation and introjected regulation, and identified regulation. However, no relationship was found between the subscales of intrinsic motivation for stimulation and amotivation. A mid-level positive relationship occurs between the sub-scales for external regulation and identified regulation although no relationship with the amotivation subscale was found. A mid-level positive relationship exists between identified regulation and amotivation. 
When the relationship from the sub-scales of the "Attitude Scale towards Social Studies" are considered, a high-level positive relationship is evident between the sub-scales for willingness to learn and enjoying Social Studies course, teacher-related attitudes and love of Social Studies. A mid-level positive relationship occurs between the sub-scales of enjoying Social Studies and teacher-related attitudes and love of Social Studies. A high-level positive relationship exists between the subscales for teacher-related attitudes and love of Social Studies.

In the qualitative part of the study, it is seen that the majority of students have positive attitudes towards Social Studies course. Additionally, students identified the following factors as being motivating for them towards the Social Studies course: the teacher being entertaining, the teacher handling of the subjects related to History, exploring and dealing with attention-grabbing course subjects, and the way the teacher taught the subject. Tahiroğlu \& Aktepe (2015) point out that motivation is important for a student to succeed in a Social Studies course. Gömleksiz \& Kan (2012) emphasize the importance of student motivation levels students in Social Studies courses where the shaping of citizenship consciousness occurs. Durmaz \& Kiriş-Avaroğulları (2016) determined that instruction by using activities was more effective and led to a significant difference in terms of the effect on student motivation in Social Studies courses. In the study by Şekerci, Doğan \& Kabapınar (2018), it is seen that using storyline approach in Social Studies courses contributes to developing a students' motivation to learn.

In the literature, generally, it can be stated that designing the teaching process with different activities will strengthen student motivation in Social Studies courses. However, in this research, students also emphasize the importance of teacher's being entertaining. In line with the results of the research, the following suggestions can be put forward:

It is important that teachers are aware of student attitudes towards the course. For this reason, it is suggested that at the beginning of each term, teachers try to determine the attitudes held by their students towards Social Studies course, and take the necessary and relevant steps. The teacher can take precautions if the student has a low-level attitude towards the course at the beginning. In this way, the student can develop a positive attitude towards the course over time.

Manner and behaviors displayed by the teacher during their teaching of the course do influence the academic motivation levels and attitudes of students towards the course. In this sense, teachers are required to pay attention to the attitude they maintain and display throughout the course.

Teachers can appeal to the individual differences amongst students by using different methods and techniques of teaching the courses. Using different methods and techniques in the courses can minimize individual differences related to the academic motivation levels and attitudes of students.

In the literature review, any study dealing with the relationship between the academic motivation levels and attitudes of students towards a Social Studies course was not encountered. It was observed that most studies were related to Science education. A contribution to the field can be made by carrying out similar studies in the field of Social Studies education. Researchers can conduct 
Faiz, M.: Karasu Avcı, E. (2020). Academic Motivation Levels of Secondary School Students...

academic studies addressing reasons that affect the academic motivation levels and attitudes of students towards courses.

\section{Conclusions}

The study aimed to reveal the academic motivation levels of middle school students and their attitudes towards a Social Studies course. An "Academic Motivation Scale" and an "Attitude Scale for Social Studies Course" were used for the quantitative part of the study. A semi-structured interview was used in the qualitative part of the study. In the study, a significant difference was observed in the Introjected Regulation levels of secondary school students in favor of male students. The scores for the Identified Regulation and Amotivation were in favor of the female students. On the other hand, no difference occurred with the school variable. According to the grade level variable, it was concluded that the motivation of the students decreased as the grade level increased.

Attitudes of secondary school students towards the Social Studies course did not differ according to gender and grade level variables. According to the school variable, a difference was observed in the attitudes of students towards the Social Studies course in favor of the school with a low socio-economic status. In the qualitative part of the research, the majority of students have positive attitudes towards the Social Studies course. Additionally, the factors which motivate the class towards the Social Studies course are the teacher's being entertaining, the handling or teaching of the subjects related to History, dealing with attention-grabbing course subjects, and the way the subject is taught.

The relationship between academic motivation levels and attitudes towards a Social Studies course shows there is a mid-level positive relationship between the academic motivation levels and attitudes of participants towards the Social Studies course. In other words, as the academic motivation levels increase, the attitudes towards the Social Studies course improves at a medium level. In this research, it was determined that both the motivation levels and attitudes of the students mutually affect each other. For this reason, increasing the motivation levels and attitudes of the students towards the Social Studies course can occur with provision of relevant course teachers. The academic success of students will increase when they have high motivation levels and a positive attitude towards the course. 


\section{References}

Adıgüzel, A. (2012). The validity and reliability study about school attitude scale. Elektronik Sosyal Bilimler Dergisi, 11 (40), 30-45.

Akbaşlı, S., Kubilay, S., \& Durnalı, M. (2017). Investigation on the future expectations and academic motivations of students attending associate degree. Journal of Human Sciences, 14(4), 4678-4693.

Akman, H. (2011). The diversification of gender and organizational statute in internal and external motivations: The research on the engineers and the technicians in Türk Telekomünikasyon A.Ş. Non-thesis master project, Süleyman Demirel University, Isparta.

Akpınar, M. (2006). The effects of students? Attitudes towards physics courses on students? Academical accomplishment in physics courses. Unpublished master's thesis, Gazi University, Ankara.

Aktaş, N. (2016). Motivation resources and decision-making strategies of high school students. Unpublished master's thesis, Adnan Menderes University, Aydın.

Altıntaş, S. (2005). The 7th grade primary school student's attitude towards social science subject. Journal of Celal Bayar University Institute of Social Sciences, 3(2), 1-12.

Altun, F., \& Yazıcı, H. (2010). Öğrencilerin okul motivasyonunu yordayan bazı değişkenler. An oral presentation of International Conference on New Trends in Education and Their Implications, Antalya.

Arıkıl, G., \& Yorgancı, B. (2012). Öğretmenlerin, öğretmen adaylarının ve öğrencilerin motivasyonu algllama farkllikları, Retrieved from http://kongre.nigde.edu.tr/xufbmek/dosyalar/tam_metin/pdf/2389-30_05_201215_25_14.pdf.

Arslan, A. (2006). The attitude scale toward making computer supported education. Yüzüncü YIl Üniversity Journal of Education, 11 (III), 24-33.

Aytaç, B. (2006). A study about the motivation of the boarding students. (Unpublished master's thesis, Kocaeli University, Kocaeli.

Balantekin, Y., \& Bilgin, A. (2017). The effect of ARCS motivational model on motivational level, attitudes and academic success of the students. Elementary Education Online, 16(1), 161-177. doi: http://dx.doi.org/10.17051/io.2017.04081

Baykara-Özaydınlık, K., \& Aykaç, N. (2014). Motivation resources and problems of candidate teachers of social studies. Mersin University Journal of the Faculty of Educaiton, 9(3), 41-55.

Bektaş, M., \& Karagöz, ş. (2017). Investigation of attitudes and motivation levels of teacher candidates in terms of some variables. International Journal of Academic Value Studies, 3(15), 154-164.

Bloom, S. (1995). Creating sanctuary in the school. Journal for a Just and Caring Education, 1 (4), 403-433.

Çakır, E. (2006). Depression and motivation levels of students who are educating in Anatolian teacher training high schools. Unpublished master's thesis, Sakarya University, Sakarya.

Canbay, F. (2016). An investigation of the relationship between academic motivation and emotional intelligence levels of ELT students at a university in Turkey. Unpublished master's thesis, Çağ University, Mersin. 
Faiz, M.; Karasu Avcl, E. (2020). Academic Motivation Levels of Secondary School Students...

Çelen, A. (2014). Examination of sixty and seventy grade students' attitudes towards social studies (Malatya sample). Unpublished master's thesis, İnönü University, Malatya.

Ceylan, E., Sağırekmekçi, H., Tatar, E., \& Bilgin, İ. (2016). Investigation of middle school students' science course achievement according to their curiosity, attitude, and motivation levels. Uşak University Journal of Social Sciences, 9(1), 39-52. https://dergipark.org.tr/tr/download/article-file/202560

Çiçek, D. (2005). Motivation and quality of work life (qwl) in organizations: A research about by determining the motivation level of managers in public organization and developing their qwl. Doctoral thesis, Çukurova University, Adana.

Çıngı, H. (1994). Ö̈nekleme kuramı. Ankara: H.U. Fen Fakuiltesi Yayınları.

Çokluk, Ö. S., Şekercioğlu, G., \& Büyüköztürk, S. (2012). Sosyal bilimler için çok değişkenli istatistik: Spss ve lisrel uygulamaları. Ankara: Pegem Akademi Yayıncllı.

Çolak, E., \& Cirık, i. (2015). Analysis of motivational orientation of secondary school students. Elementary Education Online, 14(4), 1307-1326. doi: http://dx.doi.org/10.17051/io.2015. 08906

Çöllü, E. F., \& Öztürk, Y. E. (2006). Örgütlerde inançlar-tutumlar tutumların ölçüm yöntemleri ve uygulama örnekleri: Bu yöntemlerin değerlendirilmesi. Journal of Selçuk University Social Sciences Vocational School, 9(1-2), 373-404.

Coşkun, S. A. (2009). The effect of caricatures on academic achievement, motivation and attitude in science teaching. Unpublished master's thesis, Süleyman Demirel University, Burdur.

Cronbach, L. J. (1990). Essentials of psychological testing (5th Edition). New York: Harper Collins.

Das, S. K., Halder, U. K., Mishra, B., \& Delnath, D. (2014). Study on relationship between attitude towards education and academic achievement in secondary level minority students. Indian Streams Research Journal, 4(10), 1-6.

Dawson B., \& Trapp R. G. (2001). Basic \& clinical biostatistics (3rd Edition). Lange medical Books/McGraw-Hill Medical Publishing Division.

Demir, A. (2010). The relation between the attitudes of the Students from the Second level primary school education towards social sciences and their academic success. Unpublished master's thesis, Harran University, Şanlıurfa.

Demir, S. B., \& Akengin, H. (2010). Sosyal Bilgiler dersine yönelik bir tutum ölçeğinin geliştirilmesi: Geçerlik ve güvenirlik çalışması. E-International Journal of Educational Research, 1(1), 26-40.

DeVellis, R. F. (2012). Scale development theory and application (3rd Editon). Sage Publications, Inc.

Dolunay, A. G. (2010). Segmenting Turkish university students according to lifestyle and analyzing their perception, motivation and attiude towards visual arts. Unpublished master's thesis, Marmara University, İstanbul.

Durmaz, A., \& Kiriş-Avaroğulları, A. (2016). The effect of activity practices in social studies course on students' motivation. Turkish Studies, 11 (3), 995-1010.

Ergin, A. (2006). Elementary students' attitude towards social science. Unpublished master's thesis, Pamukkale University, Denizli.

Ergin, A., \& Karataş, H. (2018). Achievement-oriented motivation levels of university students. Hacettepe University Journal of Education, 33(4), 868-887. doi: 10.16986/HUJE.2018036646 
Ergül, E. F. (2005). Motivasyon ve motivasyon teknikleri. Electronic Journal of Social Sciences, 4(14), 67-79.

Eryüksel, G. N. (1996). Ana-baba ve ergen ilişkilerinin problem çözme iletişim becerileri, bilişsel çarpıtmalar ve aile yapısı açısından incelenmesi. Unpublished doctoral thesis, Ege University, İzmir.

Fidan, M., \& Altay, E. (2017). Relationships between the profiles of middle school students' attitudes towards Turkish course and motivations for education. Hacettepe University Journal of Education, 32 (2), 480-493. doi: 10.16986/HUJE.2017024892

Gay, L. P. (1987). Educational research competences for analysis and application. Columbus: Merrill Publishing Comp.

Giannakaki, M. S. (2005). Using mixed-methods to examine teachers' attitudes to educational change: The case of the skills for life strategy for improving adult literacy and numeracy skills in England. Educational Research and Evaluation, 11 (4): 323-348. https://doi.org/10.1080/13803610500110687

Gömleksiz, M. N., \& Kan, A. Ü. (2012). A study of validity and reliability of an attitude scale on social studies course. Firat Üniversitesi Journal of Social Sciences, 23(2), 139-148.

Gömleksiz, M. N., \& Serhatıoğlu, B. (2013). Prospective teachers' perceptions of academic motivation levels. The Journal of Turkish Social Research, 17(3), 99-127.

Gopala, V., Bakar, J. A. A., Zulkifli, A. N., Alwi, A., \& Mat, R. C. (2017). A review of the motivation theories in learning. The 2nd International Conference on Applied Science and Technology'nda sunulmuş sözlü bildiri, Kedah, Malaysia.

Greene, J. C., Caracelli, V. J., \& Graham, W. F. (1989). Toward a conceptual framework for mixed-method evaluation designs. Educational Evaluation ve Policy Analysis, 11 (3), 255-274. doi: 10.2307/1163620.

Karacelil, S. (2013). The importance of motivation in religious education. Uşak University Journal of Social Sciences, 6(4), 182-207.

Karagöz Bolat, N. (2007. Motivation and success levels of 6th and 7th grade students in science and technology course at primary education with respect to learning styles. Unpublished master's thesis, Osmangazi University, Eskişehir.

Karakaya, A., \& Ay, F. A. (2007). Factors affecting the motivation of employees: A study for health employees. Journal of Celal Bayar University Institute of Social Sciences $31(1), 55-67$.

Karakuş Tayşi, E., \& Özbay, M. (2016). The development of listening attitude scale for secondary school students: Study on the validity and reliability. Journal of Mother Tongue Education, 4(2), 187-199.

Kaya, M., \& Nazıroğlu, B. (2008). Some factors affecting on the levels of professional motivation and manner of imams. Ondokuz Mayıs University Review of the Faculty of Divinity, 30, 25-53.

Kazazoğlu, S. (2011). The effect of attitudes towards mother tongue and foreign language courses on academic achievement. Doctoral thesis, Ankara University, Ankara.

Kepçeoğlu, M. (1995). Psikolojik danışma ve rehberlik. Ankara: Özerler Matbaası.

Köse, A. (2010). The relation between self-efficacy beliefs, learning and studying strategies and learning styles of science teacher candidates (ÇÖMÜ sample). Unpublished master's thesis, Çanakkale Onsekiz Mart University, Çanakkale.

Kulaksızoğlu, A. (2004). Ergenlik psikolojisi (6th Edition). İstanbul: Remzi Kitabevi. 
Faiz, M.: Karasu Avcı, E. (2020). Academic Motivation Levels of Secondary School Students...

Lukow, J. E. (2002). Learning style as predictors of student attitudes toward the use of technology in recreation courses. Unpublished doctoral thesis. Indiana University, Indiana.

Meriç, G. (2014). The effect of concept cartoons in science and technology course on students' level of conceptual understanding, motivation and attitude. Unpublished master's thesis, Celal Bayar University, Manisa.

Miles, M. B., \& Huberman, A. M. (1994). Qualitative data analysis (2nd Edition). London: Sage Publications.

Oğur, M. (2009). A research about behaviors of sixth and seventh grade students on social sciences course. Unpublished master's thesis, Pamukkale University, Denizli.

Oppenheim, A. N. (1966). Questionnaire design and attitude measurement. New York: Basic Books, Inc.

Özçelik, D. A. (1992). Eğ̈tim programları ve öğretim (Genel Öğretim Yöntemi). Ankara: OSYM Yayınları.

Özdamar, K. (2001). SPSS ile biyoistatistik (4th Edition). Eskişehir: Nisan Yayınevi.

Özgüven, I. E. (1994). Psikolojik testler. Ankara: Yeni Dogus, Matbaası.

Özgüven, I. E. (1998). Bireyi tanıma teknikleri. Ankara: Sistem Ofset.

Özkal, N., Güngör, A. \& Çetinöz, D. (2004). Teachers' ideas about the social studies course and students' attitudes towards the course. Educational Administration: Theory and Practice, 40, 600-615

Öztürk, C., \& Baysal, A. G. N. (1999). The 4th and 5th grades students' attitudes towards social studies. Pamukkale University Journal of Education, 6(6), 11-20.

Öztürk, Ö., \& Kalyoncu, N. (2014). Development of an attitude scale towards sixth grade music lesson. The Journal of Academic Social Science Studies, 25 (I), 235-248. doi: http://dx.doi.org/10.9761/JASSS2197

Papanastasiou, C. (2002). School, teaching and family influence on student attitudes toward science: Based on TIMSS data for Cyprus. Studies in Educational Evaluation, 28, 71-86. https://doi.org/10.1016/S0191-491X(02)00013-5

Patton, M. Q. (2014). Nitel araştırma ve değerlendirme yöntemleri (Translation from 3rd Edition). Çev. Edt. Mesuł Bütün, Selçuk Beşir Demir, Ankara: Pegem Akademi Yayınclik.

Sardarov, E. (2012), Attitude and behavior, unpublished master's thesis, Dokuz Eylul University, lzmir

Seker, S. E. (2015). Motivation theory. YBS Ansiklopedisi, 2(1), 22-26.

Şekerci, H., Doğan, M. C., \& Kabapınar, Y. (2018). An investigation of the effectiveness of the storyline approach-based activities in the primary school social studies lesson. Dicle Üniversity Ziya Gökalp Eğitim Fakültesi Dergisi, 33, 57-69. doi: http://dx.doi.org/10.14582/DUZGEF.1881

Selen, U. (2016). Evaluation of awareness and opinions overview of employees to internal and external motivation techniques; example of local administration. Doctoral thesis, Namık Kemal University, Tekirdağ.

Seyis, S. (2011). Relationship between high school students' motivation, emotional intelligence and academic achievement. Unpublished master's thesis, Karadeniz Teknik University, Trabzon.

Sidekli, S. (2010). Illköğretim beşinci sınıf öğrencilerinin 2004 programı doğrultusunda Sosyal Bilgiler dersine yönelik tutumları. Turkish Journal of Social Research, 3, 1-23. 
Stirling, D. (2013). Motivation in education. Aichi Universities English Education Research Journal, 29, 51-72.

Tabachnick, B. G., Fidell, L. S., \& Ullman, J. B. (2007). Using multivariate statistics. MA: Pearson.

Tahiroğlu, M., \& Aktepe, V. (2015). Validity and reliability study on the motivation scale form designed for 4 th and 5 th grade social studies course. Turkish Studies, 10(3), 907-932.

Taşkın, Y. O. (2015). The relationship between pre-service teachers' value orientation and academic motivation. Unpublished master's thesis, Çanakkale Onsekiz Mart University, Çanakkale.

Tay, B., \& Akyürek Tay, B. (2006). The effects of attitude on success in social sciences courses. Türk Eğitim Bilimleri Dergisi, 4(1), 73-84.

Tohidi, H., \& Jabbari, M. M. (2012). The effects of motivation in education. Procedia-Social and Behavioral Sciences, 31, 820-824.

Türk, A. (2018). Investigation of academic motivation and cyber bullying for 6 th and 7 th grade students. Unpublished master's thesis, Toros University, Mersin.

Türk, C., Kalkan, H., Semercioğlu, M., \& Bolat, M. (2017). Developing students' motivation and attitudes towards science with a nature education project. Journal of Research in Educaiton and Teaching, 6(3), 334-341.

Tütüncü, Ö., \& Küçükusta, D. (2007). Organizasyonlarda bireyler: tutum, davranış ve motivasyon. Retrieved from http://web.deu.edu.tr/kalite/dosyalar/ulusal_ bildiri/EkD.doc

Vallerand, R. J., Blais, M. R., Brière, N. M., \& Pelletier, L. G. (1989). Construction et validation de l'Échelle de Motivation en Éducation (EME). Revue Canadienne Des Sciences Du Comportement, 21, 323-349.

Vatansever Bayraktar, H. (2015). Student motivation in classroom management and factors that affect motivation. Turkish Studies, 10(3), 1079-1100. doi: http://dx.doi.org/10.7827/ TurkishStudies.7788

Vero, E., \& Puko, E. (2017). The importance of motivation in an educational environment. Formazione \& Insegnamento, XV (1), 57-66.

Wilkesman, U., Fischer, H., \& Virgillito, A. (2012). Academic motivation of students-the German case. Technische Universitat, Dortmund.

Yavuz, F. (2006). School motivation assessment scale arrangement and reliability. Unpublished master's thesis, Marmara University, istanbul.

Yavuz, H. (2014). Student opinions on effectiveness of student services and motivation levels at open education vocational high school. Unpublished master's thesis, Fatih University, istanbul.

Yetim, E., Demir, Y., \& Erduran Illker, G. (2014). Motivation in physical education: The predictive effect of attitude and motivational strategies. Spormetre the Journal of Physical Education and Sport Sciences, 12 (2), 139-146.

Yıldırım, A., \& Şimşek, H. (2013). Sosyal bilimlerde nitel araştırma yöntemleri. Ankara: Seçkin Yayıncllik.

Yilmazer, A., \& Demir, S. B. (2014). An investigation into the relationship between learners' academic achievement and their attitudes towards social studies lesson and the teacher. Turkish Studies, 9(2), 1705-1718. 
Yöyen, i. (2008). Comparison of the level of motivation and depression of the students within for improving professional and technical training. Unpublished master's thesis, Beykent University, İstanbul.

Yurt. E., \& Bozer, E. N. (2015). The adaptation of the academic motivation scale for Turkish context. Gaziantep University Journal of Social Sciences, 14(3), 669-685.

\section{Biographical Statements}

Melike FAiz is an assistant professor in the Social Sciences Education program at the Department of Turkish and Social Sciences Education in Kastamonu University, Faculty of Education. She has national and international studies in the field of Social Studies education.

Emine KARASU AVCl is an assistant professor in the Social Sciences Education program at the Department of Turkish and Social Sciences Education in Kastamonu University, Faculty of Education. She has national and international studies in the field of Social Studies education.. 